\title{
THE USE OF GENETIC MARKERS IN THE FIGHT AGAINST MASTITIS
}

\section{WYKORZYSTANIE MARKERÓW GENETYCZNYCH W ZWALCZANIU ZAPALENIA WYMIENIA}

Department of Ruminant Science, West Pomeranian University of Technology, Szczecin, Poland

${ }^{1}$ Sano-Modern Animal Nutrition Limited Company, Sękowo, Poland

\begin{abstract}
Streszczenie. Celem pracy było scharakteryzowanie choroby zapalenia wymienia, przedstawienie różnych metod leczenia i zapobiegania powstania mastits. Do tradycyjnych sposobów zalicza się zachowanie higieny podczas udoju i po nim, czystości w oborze, stosowanie szczepionek oraz antybiotykoterapię. Metody tradycyjne okazały się zbyt czasochłonne i kosztowne, więc rozpoczęto badania nad genami, które mogą być odpowiedzialne za zapalenie wymienia. Metoda MAS wykorzystuje markery genetyczne w celu wyselekcjonowania osobników z większą odpornością na mastitis. Technika ta ma na celu nie tylko poprawę zdrowia u krów, ale również zwiększenie produktywności mlecznej, która jest istotna ze względów hodowlanych. Laktoferyna oraz gen BoLA zostały przedstawione jako geny, które mogą być markerami genetycznymi przeciwko mastitis dzięki swoim bakteriostatycznym właściwościom.
\end{abstract}

Słowa kluczowe: markery genetyczne, zapalenie wymienia.

Key words: genetic, markers mastitis.

\section{INTRODUCTION}

The development of biotechnology sciences, especially genetic engineering made it possible to get to know the genotypes of animals. Thanks to this information, the scientists can identify specific genes responsible for resistance to certain diseases, production traits or other aspects of importance in animal husbandry. Thanks to the tools of molecular genetics, such as PCR-RFLP technique, DNA isolation, one discovered genetic markers that have a positive effect on the progress of husbandry, resulting in economic advantages.

Mastitis is a common disease in dairy cows. Veterinary methods are not sufficient to prevent the incidence of mastitis. Researchers found in their studies that the disease is genetic. Using modern molecular techniques, it is possible to identify the genes responsible for mastitis (Sender et al. 2006).

The aim of the study was to evaluate the use of selected genetic markers in mastitis in dairy cows.

Corresponding author - Adres do korespondencji: Ewa Czerniawska-Piątkowska, Department of Ruminant Science, West Pomeranian University of Technology, Szczecin, Doktora Judyma 10, 71-460 Szczecin, Poland, e-mail: ewa.czerniawska-piatkowska@zut.edu.pl 


\section{MASTITIS}

Mastitis is one of the most difficult in treatment diseases of dairy cattle. This disease entails huge financial costs (Plewik and Jażdże-Maszkowska 2016) and causes huge losses in cattle husbandry (Sender 2001), e.g. lower milk yield of animals, deterioration in the composition and quality of milk (Bogucki and Sawa 2002), increased costs of treatment, which ultimately leads to unprofitable milk production (Gnyp et al. 2006).

\section{CAUSES OF DISEASE}

Mastitis is a hardly treatable disease because of the presence of many pathogens. The etiological agents are bacteria, viruses, fungi and protozoa. Depending on the characteristics of the etiologic agent, they can be divided into infectious or environmental. Among the infectious bacteria we distinguish among others $S$. auerus, $S$. agalactiae and $M$. bovis (Rossito et al. 2002). The place of occurrence of the above-mentioned pathogens is the mammary gland of infected animals. These bacteria cause long-term subclinical infection, but in a sick herd one can observe an increased number of somatic cells (Niewitecki 2014). Mastitis caused by environmental microorganisms is a cause of formation of clinical disease (Bednarski et al. 2014.) They are in the immediate vicinity of the cow, for example in litter, manure and soil. The bacteria included in the group are: S. dysgalactiae, S. uberis, Enterococcus spp. and E. coli, Klebsiella and Enterobacter. Apart from them, the environmental pathogens are also fungi and algae (Costa et al. 1998). Infection with bacteria of the Enterobacteriaceae group (including E. coli) causes severe inflammation in particular at high yielding cows (Malinowski 1997).

\section{PREVENTION AND TREATMENT}

The common element in the treatment and prevention of mastitis is antibiotic therapy, which is important in controlling the disease by reducing the level of infection in the breeding of cows and preventing the newly established (Unakal and Kaliwal 2012). The strategy to combat mastitis in a herd of dairy cows is based on the classification of the main pathogen to one of the groups of etiological factors (Niewitecki 2014). Another important step is the proper preparation of udders before milking, care about the cleanliness of the udders of cows and ensuring hygiene of the place of their existence. According to research of Malinowski (2011) it was found that the percentage of clinical form of mastitis was correlated with the type of lining used for rooms for cows (Malinowski et al. 2011). An important indicator for the identification of diseases of the mammary gland is the level of somatic cells (SCC) in milk. Excessive volumes can cause inflammation of the udder (Harmon 1994), so one should regularly monitor their number (Sender et al. 2005; Kupczyński 2009).

\section{GENETIC MARKERS}

The costs and difficulties in the treatment of mastitis has forced the dairy cattle breeders to use different selection methods. Sender and Reklewski (2002) demonstrated scientifically that the mastitis may also have a genetic basis and is dependent on the number of genes. In 
order to reduce the susceptibility to the disease, one began to use a selection method in order to select bulls with lower level of transmission of the disease. Some of these procedures included examination of the number of somatic cell count (SCC) in milk, observation of clinical signs of daughters of tested bulls. This disease has low heritability (Sender 2001) and the selection based on the genes method can take too long. Another selection method is the use of genetic markers, the so-called MAS selection. This technique uses markers to detect specific sites on chromosomes where genes are located, and they may affect the incidence of mastitis (Sender et al. 2003). MAS selection theory has been assessed positively. This suggests that its use in husbandry can increase the efficiency of selection, reduce the gaps between selected generations and minimize the cost (Bishop et al. 2002).

\section{LACTOFERRIN GENE POLYMORPHISM}

Lactoferrin (Lf, LTF) is a glycoprotein with a mass of $80 \mathrm{kD}$. It is present in the secretions of the epithelial cells, e.g. milk, saliva, tears. This protein belongs to the transferrin group and has a high affinity for iron ( $\mathrm{Fe} 3+)$. Lactoferrin, capturing and binding free iron in the body, reduces the availability of this element for the microorganisms and slows their growth. This mechanism of action affects among others the bacteriostatic activity of lactoferrin (Gajda-Morszewski and Singer 2015). The concentration of lactoferrin in cows' milk is variable depending on various factors. Hagiwara et al. (2003) in order to determine the concentration of lactoferrin in the milk took into account factors determining changes in the concentration of age (2-6 years), stage of lactation (early, middle, late), the number of somatic cells (SSC0-SCC7), the kind of bacteria ( $S$. aureus, $S$. agalaciate, coagulase - negative staphylococci, other streptococci, C. bovis).

Using laboratory tests and statistical data, they determined that the concentration of lactoferrin in the milk of cows suffering from mastitis is much higher $(2.70 \mu \mathrm{g} / \mathrm{ml})$ than for normal milk $(2.23 \mathrm{\mu g} / \mathrm{ml}$. This was due to the presence of bacteria and thus more somatic cells. The greatest concentration of Lf was found for the following bacteria: $S$. aureus $-2.83 \mu \mathrm{g} / \mathrm{ml}$ and $S$. agalactiae $-2.90 \mu \mathrm{g} / \mathrm{ml}$. The lowest concentration was determined for the bacteria C. bovis $-2.37 \mu \mathrm{g} / \mathrm{ml}$.

A healthy cow's milk obtained significantly lower scores, Hagiwara et al. (2003) found that age and stage of lactation had an impact on the increase or decrease in the concentration of globule protein. The highest score was obtained for young cows ranging in age from two to three years $-2.4-2.30 \mu \mathrm{g} / \mathrm{ml}$. The lowest - the oldest cows $-2.02 \mu \mathrm{g} / \mathrm{ml}$. The step of lactation also is important. In the latest stage, the concentration of lactoferrin was $2.30 \mu \mathrm{g} / \mathrm{ml}$, and in the early one only $2.06 \mu \mathrm{g} / \mathrm{ml}$. Kamiński et al. (2006) analyzed the mutated fragment of lactoferrin in $+32(\mathrm{C} / \mathrm{G})$ position. For the study they used blood samples from 358 cows of Holstein-Friesian variety being in first lactation. With the techniques of molecular biology, one identified three genotypes GG, GC, CC of the following frequencies: $0.628,0.313$ and 0.059 . The authors concluded that the CC genotype had the highest milk yield and was characterized by a smallest number of somatic cells, but these differences were not statistically significant. C allele had a significant impact on the amount of protein and its percentage content in the milk, but it was not significant for a number of somatic cells. Similar 
studies in search of a genetic marker in the form of lactoferrin was conducted by Sender et al. (2012). For this purpose, blood was taken from 698 cows of Holstein-Friesian black white variety. The average milk yield in 305 days of lactation was $9662 \mathrm{~kg}$ (fat $-367 \mathrm{~kg}$ (3.85\%), protein $-323 \mathrm{~kg}(3.36 \%)$. The average number of somatic cells in milk was 531 thous $/ \mathrm{ml}$. In the analyzed herd one separated three genotypes of the following frequencies $A A-0.54$, $A B-0.38$, $B B-0.08$. Sender et al. (2012) found that more than $50 \%$ of the tested herd had the AA genotype, while the BB genotype was the least frequent (8\%). A similar BB genotype frequency was stated in other works (Sender et al. 2006; Wojdak-Maksymiec et al. 2006). Based on the performed studies, it was determined that the frequency of allele B occurrence is about 3.81 times smaller than for the A allele. Previous studies (Sender et al. 2006; Sender et al. 2007) have shown that dairy cows with the BB genotype are less prone to mastitis. On the other hand, this genotype is not preferred from the viewpoint of breeding. The cows with BB genotype are characterized by a low milk yield, often causing a slow elimination of allele B in order to improve productivity. The results obtained by Sender et al. (2012) were compared with research of Wojdak-Maksymiec et al. (2006). They found a diverse number of somatic cells for specific genotypes, but the results obtained by them overlap with the work of Sender et al. (2012). The lowest number of LKS was stated for animals with AA lactoferrin genotype, and the highest with $A B$ genotype. The authors reported that the best in terms of production were cows with $A B$ and $B B$ genotypes because they were characterized by a low number of somatic cells, however, the BB genotype occurred very rarely.

\section{BoLA-DRB3 GENE}

BoLA gene belongs to the major histocompatibility complex (MHC), which is responsible for immunological mechanisms and morbidity. These genes are located on chromosome 23 and are divided into classes I and II. Depending on the classification, they occur on other cells (Sender et al. 2005). In the case of class II BoLA genes, the most thoroughly researched and known gene is DRB3. It is characterized by high polymorphism, there are over 90 different alleles (Van Eijk et al. 1992). The research found that some allelic association may have an impact on the incidence of mastitis in cattle. In order to find the connection of BoLA genes with the incidence of mastitis, the research teams around the world have begun a detailed study of the components of the MHC.

Due to the multifunctonality of the lactoferrin protein, and in particular its role in combating bacterial infections, Sender et al. (2006) in their studies decided to determine the effect of Ltf polymorphism and BoLA-DRB3 gene on the number of somatic cells in cow's milk. The sample was constituted of 125 Holstein cows from which the milk samples were taken to determine the number of somatic cells, and blood to study BoLA-DRB3 gene and lactoferrin polymorphism. By PCR-RFLP method, they found that there are two alleles of $A$ and $B$ lactoferrin in the following order: $80 \%$ and $20 \%$. Most of the works confirmed the received frequency. One of the purposes of the study was to determine the effect of polymorphism of lactoferrin on the amount of SCC. The lowest number was found in individuals with BB genotype (5.47) and the highest for AB (6.03). The authors Sender et al. (2012) obtained similar results for the BB genotype, which was marked by the lowest number of somatic cells, 
but the turnout and the number of individuals with the genotype was too small to statistically confirm this. In other studies, Sender et al. (2005) conducted research on BoLA-DRB3 gene polymorphism and its impact on the incidence of mastitis. To this end, they studied a total of 130 Holstein cows from which samples of milk were taken to help determine the amount of somatic cells. BoLA-DRB3 gene polymorphism was examined on the basis of blood samples. One separated two alleles of this gene, 16 and 23 with the following turnout $14.2 \%$ and $10 \%$. A similar share of alleles was observed in research on Holstein cows (Kelm et al. 1997). In terms of research, they obtained different results. This could be due to the fact that research of Sender et al. (2005) covered a small research pool and in other studies the sample accounted for even more than 1,000 cows. Individuals with BoLA-DRB3 gene *16 allele were characterized by the lowest number of somatic cells in milk (5.59), while in the case of two alleles -16 and 23 at the same time, the result has increased and was characterized by the highest number of SCC (6.41).

Pashmi et al. (2009) have examined the polymorphism of BoLA-DRB3 gene and the connection of alleles with increased number of somatic cells as well as the milk yield. For this purpose, they acquired blood samples from 262 Iranian cows of Holstein breed. After the procedures, the mean milk yield values obtained were $-28.64 \mathrm{~kg}$, fat $-3.45 \mathrm{~kg}$ protein $3.13 \mathrm{~kg} .25 \%$ of the total number of somatic cells was more than 300000 thous $/ \mathrm{ml}$. They identified 28 alleles of BoLA-DRB3 gene, including a new, previously unrecognized allele * 40 with the turnout of $0.38 \%$. The most common alleles were ${ }^{*} 8,{ }^{*} 11,{ }^{*} 16,{ }^{*} 22,{ }^{*} 23,{ }^{*} 24$ and * 51 in the frequency of $75.38 \%$ of the total study population, among them *24 allele was characterized by the highest turnout -17.94 .

In studies of Kelm et al. (1997) and Nassiry et al. (2005) on the BoLA-DRB3 gene there has also been the same allele at a similar frequency. The fat content in milk was influenced by allele * 11 and * 22 , protein by* 22 and ${ }^{*} 24$, and ${ }^{*} 51$ and ${ }^{*} 8$ showed no binding to the characteristics of milk production. * 22 allele had a visible impact on improving the performance characteristics of milk, but also had the highest number of SCC (7.65) which meant less resistance to mastitis. A similar trend was observed for allele * 8 (5.80) and * 51 (7.24). The level of SCC in milk of BoLA-DRB gene ${ }^{*} 22$ allele is dependent on the lactation period. The increased level was observed in the first and third lactation (Starkenburg et al. 1997), but it lowered in the second period (Dietz et al., 1997). The breed cows also had an impact on the number of somatic cells in milk.

Studies of Rupp et al. (2007) showed that individuals of Norwegian and Canadian varieties of Red Holstein suffered from subclinical mastitis and had elevated SCC. It has been found that the * 8 allele causes increase of LKS, lack of resistance to mastitis and more frequent incidence of mastitis (Dietz et al. 1997; Rupp et al. 2007). Nassiry et al. (2005) were the first researchers who studied the polymorphism of BoLA-DRB3 gene on the example of Holstein cows. In the studied flock, this gene is highly polymorphic, since they identified 26 alleles. $67 \%$ of the alleles detected were four most common alleles * $8,{ }^{*} 24,{ }^{*} 11$ and ${ }^{*} 16$, one allele * 8 had a higher incidence than the other and it was $26.6 \%$. Other alleles appeared in the incidence of less than $1 \% .{ }^{*} 22,{ }^{*} 2$ and ${ }^{*} 16$ alleles had influence on the health of cows and their reproductive system, caused less risk of cysts on the ovaries. Alleles associated with the incidence of mastitis infection and leukemia - * 11 and * 23 occurred with the following turnout: $10.4 \%$ and $4.4 \%$. 
BoLA-DRB3 gene affects many aspects of the health of cows, their milk productivity. Depending on the population studied, breed, lactation period, the material collected, the alleles can have a positive or negative effect and result in increased somatic cell count, resulting in the occurrence of mastitis. Scientists are still conducting research to discover even more polymorphisms and their significance for cattle.

\section{CONCLUSIONS}

Mastitis disease is very common among dairy cows. Treating it is time consuming, expensive and often difficult. The reason for this is the presence of large amounts of the determinants of the disease. Environmental factors and hygiene in the barn have an impact on the health of the cows, but later it turned out that genetic differences are also important. The conducted studies using MAS selection show an improvement in the health of cattle, increased milk yield and reduced expenses. In comparison with other methods of treating mastitis, selection using genetic markers should be appropriate for diseases of low heritability and heal the cows quicker. Understanding the molecular basis of genetic disease, particularly those for which several genes are responsible is difficult. Research work on the ideal candidate for genetic marker against mastitis is still in progress, since it is important to use all the data about gene in the body. Lactoferrin is a protein very well understood and tested for use in the fight against mastitis. Most of the studies of polymorphism confirm the effectiveness of lactoferrin on the reduction of incidence of this disease, thanks to bacteriostatic characteristics. BoLA gene belongs to the major histocompatibility complex $(\mathrm{MHC})$, which functions in regulating the immune response, so it recognizes the foreign proteins. Based on the performed analyses of BoLA-DRB3 gene, polymorphism in exon 2 of this gene is associated with the mastitis disease.

\section{REFERENCES}

Bednarski M. 2013. Choroby bydła. Podstawy diagnostyki i terapii. [b.m.], Apra - Wetpress. [in Polish]

Bishop S.C., Chesnais J., Stear M.J. 2002. Breeding for disease resistance: issues and opportunities, in: Proceedings of the 7th World Congress on Genetics Applied to Livestock Production, Montpellier August 2002, Montpellier, France, 19-23.

Bogucki M., Sawa A. 2002. Wydajność dobowa i jakość mleka jako efekt współdziałania genotypu i wybranych czynników pozagenetycznych [The combined effect of genotype and selected non-genetic factors on dailymilk yield andmilk quality]. Acta Sci. Pol. Zootech. 1(1-2), 5-16. [in Polish]

Costa E.O., Ribeiro A.R., Watanabe E.T., Melville P.A. 1998. Infectious bovine mastitis caused by environmental organisms. J. Vet. Med. B. 45, 65-71.

Dietz A.B., Cohen N.D., Timms L., Kehrli M.E. Jr. 1997. Bovine lymphocyte antigen class II alleles as risk factors for high somatic cell counts in milk of lactating dairy cows. J. Dairy Sci. 80, 406-412.

Gajda-Morszewski P., Śpiewak K. 2015. Laktoferyna - białko multipotencjalne [Lactoferrin multipotential protein]. Zesz. Nauk. Tow. Nauk. UJ 10(1), 177-188. [in Polish]

Gnyp J., Kowalski P., Tietze M. 2006. Wydajność mleka krów, jego skład i jakość cytologiczna w zależności od niektórych czynników środowiskowych [Cow milk performance, composition and cytological quality depending on certain environmental factors]. Ann. UMCS 24(3), 17-26. [in Polish]

Hagiwara S., Kawai K., Anri A., Nagahata H. 2003. Lactoferrin concentrations in milk from normal and subclinical mastitic cows. J. Vet. Med. Sci. 65(3), 319-323. 
Harmon R.J. 1994. Physiology of mastitis and factors affecting somatic cell counts. J. Dairy Sci. 77, 2103-2112.

Kamiński S., Olenski K., Brym P., Malewski T., Sazanov A. 2006. Single nucleotide polymorphism in the promoter region of the lactoferrin gene and its associations with milk performance traits in Polish Holstein-Friesian cows. Russian J. Genet. 42(8), 924-927.

Kelm S.C., Detilleux J.C., Freeman A.E., Kehrli M.E., Dietz A.B., Fox L.K., Butler J.E., Kasckovics I., Kelley D.H. 1997. Genetic association between parameters of innate immunity and measures of mastitis in periparturient Holstein cattle. J. Diary Sci. 80, 1767-1775.

Kupczyński R. 2009. Mastitis pod lupą [Mastitis under the microscope]. Trouw i My 5, 3-5. [in Polish]

Malinowski E., Gajewski Z., Pawliński B., Nagas T., Perzyna M. 2011. Zapobieganie colimastitis u krów [Prevention of colimastitis in cows]. Życie Weter. 86(2), 114-117. [in Polish]

Malinowski E. 1997. Przyczyny, leczenie i zapobieganie mastitis u krów. Puławy, PiWet. [in Polish]

Nassiry M.R., Shahroodi F.E., Mosafer J., Mohammadi A., Manshad E., Ghazanfari S., Mohammad Abadi M.R., Sulimova G.E. 2005. Analysis and frequency of bovine lymphocyte antigen (BoLA-DRB3) alleles in Iranian Holstein cattle. Genetika 41(6), 817-22.

Niewitecki P. 2014. Znaczenie bakteriologicznego badania mleka [Importance of bacteriological milk testing]. Now. Rol. wrzesień/październik, 22-23. [in Polish]

Pashmi M., Qanbari S., Ghorashi S.A., Sharifi A.R., Simianer H. 2009. Analysis of relationship between bovine lymphocyte antigen DRB3.2 alleles, somatic cell count and milk traits in Iranian Holstein population. J. Anim. Breed Genet. 126(4), 296-303.

Plewik M., Jażdż-Maszkowska M. 2016. Nowoczesne podejście do zwalczania mastitis - doniesienia terenowe nt. wdrożenia kompleksowego programu kontroli jakości mleka na fermie bydła mlecznego zakażonej gronkowcem złocistym [A modern approach to mastitis management; implementation of complex milk quality control program on dairy farm with Staphyloccocus aureus infected cows]. Weter. Ter. 1, 50-55. [in Polish]

Rossito P.V., Ruiz L., Kikuchi Y., Glenn K., Luiz K., Watts J.L., Cullor J.S. 2002. Antibiotic susceptibility patterns for environmental streptococci isolated from mastitis in central California dairies. J. Dairy Sci. 85, 132-138.

Rupp R., Hernandez A., Mallard B.A. 2007. Association of bovine leukocyte antigen (BoLA) DRB3.2 with immune response, mastitis, and production and type traits in Canadian Holsteins. J. Dairy Sci. 90, 1029-1038.

Sender G., Dymnicka M., Korwin-Kossakowska A., Gralak B., Arkuszewska E., Łozicki A. 2007. Związek polimorfizmu genu laktoferyny z wydajnością mleka [Relationship of lactoferrin gene polymorphism with milk yield]. Rocz. Nauk. PTZ 3(4), 97-101. [in Polish]

Sender G., Korwin-Kossakowska A., Galal Abdel Hameid K., Prusak B. 2006. Ocena wpływu polimorfizmu wybranych genów na występowanie mastitis u krów [Evaluate the effect of polymorphism of selected genes on the occurrence of mastitis in cows]. Med. Weter. 62(5), 563-565. [in Polish]

Sender G., Korwin-Kossakowska A., Gralak B. 2005. Wpływ polimorfizmu genu BoLA-DRB3 na występowanie mastitis u krów [Effect of BoLA-DRB3 polymorphism on mastitis in cows]. Med. Weter. 61, 540-542. [in Polish]

Sender G., Korwin-Kossakowska A., Stępińska U. 2003. Wykorzystanie markerów genetycznych w programie zwalczania mastitis [Use of genetic markers in the mastitis control program]. Med. Weter. 59(10), 853-856. [in Polish]

Sender G., Oprządek J., Pawlik A., Urtnowski P., Kubasik D. 2012. Możliwości wykorzystania polimorfizmu genu laktoferyny w selekcji krów odpornych na zapalenie wymienia [Possibilities of using polymorphism of the lactoferrin gene in the selection of cows resistant to inflammation]. Rocz. Nauk. PTZ 8(1), 9-16. [in Polish]

Sender G., Reklewski Z. 2002. Komórki somatyczne w indeksie selekcyjnym bydła mlecznego w Polsce [Somatic cells in the dairy cattle selection index in Poland]. Biul. Inf. IŻ 2, 39-52. [in Polish] 
Sender G. 2001. Odporność na mastitis jako składowa celu hodowlanego w programach doskonalenia bydła mlecznego [Resistance to mastitis as a component of breeding purpose in dairy cattle improvement programs]. Pr. Mater. Zoot. 12, 1-61. [in Polish]

Starkenburg R.J., Hansen L.B., Kehrly M.E. Jr., Chester-Jones H. 1997. Frequencies and effects of alternative DRB3.2 alleles of bovine lymphocyte antigen for Holsteins in milk selection and control lines. J. Dairy Sci. 80, 3411-3419.

Unakal C.G., Kaliwal B.B. 2012. Prevalence and antibiotic susceptibility of Staphylococcus aureus from bovine mastitis. Vet. World 3, 65-67.

Van Eijk M.J., Stewart-Haynes J.A., Lewin H.A. 1992. Extensive polymorphism of the BoLA-DRB3 gene distinguished by PCR-RFLP. Anim. Gen. 23, 483-485.

Wojdak-Maksymiec K., Kmieć M., Ziemak J. 2006. Associations between bovine lactoferrin gene polymorphism and somatic cell count in milk. Veter. Med. 51(1), 14-20.

Abstract. The purpose of the paper was to characterize mastitis, present different methods of treatment and prevention of emergence of mastits. Conventional methods include hygiene during milking and after it, the cleanliness in the barn, the use of vaccines and antibiotic therapy. Traditional methods have proven to be too time consuming and costly, therefore, one has started research on genes that may be responsible for mastitis. The MAS method uses genetic markers to select animals with higher resistance to mastitis. This technique is designed not only to improve the health of cows, but also to increase productivity of milk, which is important for the breeding aspects. Lactoferrin and BoLA gene were presented as candidate genes for genetic markers against mastitis, due to their bacteriostatic properties. 